\title{
Nutritional profile and phytochemical composition of Gardenia sokotensis (Boscia of the rock)
}

\author{
Muhammad M. U., "Kwazo H. A., Abubakar L., Bagna E. A. \\ Department of Chemistry, Shehu Shagari College of Education, Sokoto \\ *Corresponding Author's Email:khadijahkwazo@gmail.com
}

\begin{abstract}
Plant information are vital to assess and develop nutrition, food security policies, traditional medicine and its significance in the distribution of these chemical constituents, as a result, the nutritional and phytochemical composition of Gardenia sokotensis pulp and seeds were analyzed. The moisture content, ash content, crude lipid, crude protein, crude fibre, calorific energy value and available carbohydrate were analyzed on dry weight bases. All the determinants were carried out in triplicates. The pulp had high value of ash $(17.88 \pm 0.41 \%)$, moisture $(21.71 \pm 0.00 \%)$ and crude lipid $(53.96 \pm 1.59 \%)$ while the seeds had high value of crude protein $(13.04 \pm 0.47 \%)$, crude fibre $(17.65 \pm 0.14 \%)$, carbohydrate $(9.67 \%)$ and energy value $(1445.87 \mathrm{Kcal})$. The anti-nutritional factors for pulp and seeds were phytate $(0.14 \pm 0.00),(2.30 \pm 0.00)$, oxalate $(1.10 \pm 0.00),(1.10 \pm 0.00)$, nitrate $(0.04 \pm 0.00),(0.14$ $\pm 0.00)$, cyanide $(0.12 \pm 0.00),(0.21 \pm 0.00)$ and tannins $(0.21 \pm 0.00),(0.27 \pm 0.00)$ respectively and all were within the tolerable level. The results of mineral analysis of the seeds and pulp showed different concentration of the element, $\mathrm{Na}$ (106.67 and 85.83), $\mathrm{K}(5700$ and 7666.67$), \mathrm{Ca}(0.6833$ and 0.4333$), \mathrm{Mg}$ (0.2500 and 0.8266), Fe (4.2914 and 6.7959), Zn (1.3639 and 0.1522), $\mathrm{Cu}$ (1.5298 and 2.1755), $\mathrm{Cr}$ (0.0096 and 0.0163$), \mathrm{Mn}(0.2615$ and 0.3101$), \mathrm{Pb}(0.0594$ and 0.0657$)$, Co $(0.0447$ and 0.1195$)$ and for phosphorus (3.4700 and 10.3000). Phytochemical screening indicated the presence of alkaloid, saponins, steroids, tannins, cardiac glycosides and flavonoids. Based on these results, seeds and pulp of Gardenia sokotensis contains appreciable amount of nutrients and secondary metabolite which could serve as a supplementary source of food and new drug discovery for the benefit of humans and livestock.
\end{abstract}

Key words: Nutritional profile, Phytochemical, Anti-nutritional, Gardenia sokotensis, Mineral.

\section{INTRODUCTION}

Due to the on hand monetary pressure in our developing countries like Nigeria, considerable population mainly low and middle income earners rely on their natural habitat food. Food shortage is becoming evident as a result of population intensification. In Africa, studies indicated that enormous number of native wild plant exist and play a significant role in the diet of masses (Umar and BirninYauri, 2008).

Some of these wild plants that are used by people as food and sources of nutrients are fruits; fruits are good sources of protein, fats, carbohydrate and minerals (Bello et al., 2008). Research have shown that fruits not merely contain nutritionally important bio- compounds but are also sources of other phyto-compounds which at certain grade levels have significant anti-nutritional effect (Omoruyi et al., 2007).

Gardenia sokotensis of the Rubeacea family belongs to the Genus Gardenia in the phylum Tracheophyta, commonly called 'Ànzándúútsè' in Hausa and Boscia of the rock in English. It is a shrub/tree of $3-4 \mathrm{~m}$ high, with stipules and bisexual flowers. It consists of pistil, carpels and a single style. The fruits are yellow in colour and oval in shape when mature, which is a seasonal fruit mostly available during harmattan and is eaten raw. The pulp is eaten as food and the seeds are thrown away as waste (Ozaki et al., 2002). 


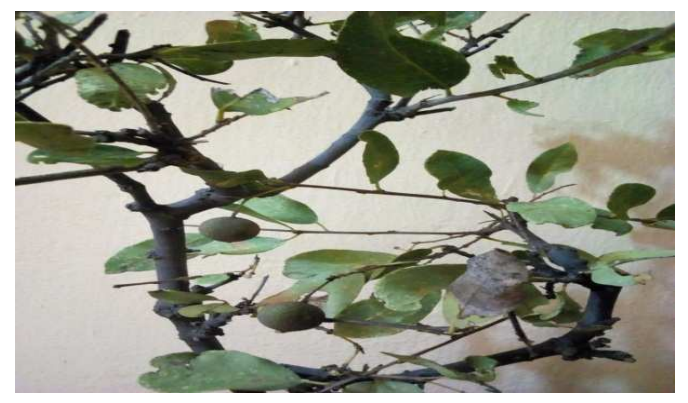

Figure 1.Gardenia sokotensis plant

The fresh leaves of Gardenia sokotensis are eaten as food, and the fruits are eaten as snacks, while the matured leaves are boiled and the water extract is taken as anti-malaria and seeds were found to treat impotence in men if soaked in water and drank (Hockett et al., 2000). Therefore, the aim of this research was to evaluate the nutritional profile and phytochemical composition of the pulp and the seeds of Gardenia sokotensis to ascertain its contribution to the general populae in world of food.

\section{MATERIALS AND METHODS}

\section{Sample collection and identification}

Ripped fruits of Gardenia sokotensis were obtained from different plants of various locations in Kalausa, DangeShuni local government area of Sokoto state, Nigeria. The samples were mixed together and picked at random (Asaolu and Asaolu, 2002). The fresh fruits were identified at Botany unit of the Department of Biological Sciences, Usmanu Danfodiyo University Sokoto, Nigeria.

\section{Sample treatment}

The sample fruits were washed with distilled water to avoid surface contamination (Ahmad and BirninYauri, 2008). The pulp of the fruit and the seeds were separated using plastic spoon after dividing the fruit into two. The samples were dried under the shade for two weeks at room temperature, crushed to a fine powder using mortar and pestle, sieved through 20 $\mathrm{mm}$ mesh and stored in air tight plastic containers for further analysis.

\section{Proximate analysis}

Proximate analysis of ripped fruits of Gardenia sokotensis powder was carried out which is a system of analysis of nutrients in which the gross components rather than the individual nutrients of amino acids, fatty acids and monosaccharides are determined (Adesuyi et al., 2012).
The following are the constituent parameters: moisture, ash, crude protein, fat, crude fibre and carbohydrate. All of these were carried out using the method of analysis described by AOAC (1990). Available carbohydrate was estimated (by difference) using method described by James (1995). Calorific value (in Kcal/100g) was estimated by multiplying the percentages of crude protein, crude lipids and available carbohydrate by factors of 4.9 and 4.0 respectively and the product summed up (James, 1995).

\section{Mineral analysis}

The atomic Absorption spectrophotometer (AAS) was used for the analysis of $\mathrm{Ca}, \mathrm{Mg}, \mathrm{Cu}, \mathrm{Zn}, \mathrm{Fe}, \mathrm{Mn} \mathrm{Cr}, \mathrm{Co}$, $\mathrm{Ni}, \mathrm{Cu}$ and $\mathrm{Pb}$. Phosphorus was determined using calorimeter, while the Flame Photometer was used in the analyses of $\mathrm{K}$ and $\mathrm{Na}$. All of these were carried out using the method of analysis described by Adesuyi et al., (2012).

\section{Anti - nutritional analysis}

The method of Ola and Oboh (2000) was adapted for the determination of Phytate and Tannins. Hydrocyanic acid was determined by AOAC (1990). Oxalate and nitrate were determined by the methods of Krishna and Ranjhan (1980).

\section{Phytochemical analysis}

Phytochemical analysis includes the tannin determination, determination of saponin, steroids, alkaloids, cardiac glycosides, flavonoids and anthraquinone. All of these were determined based on methods of analyses described by AOAC (1990).

\section{RESULTS AND DISCUSSION}

\section{Proximate analysis}

The proximate analysis of Gardenia sokotensis seeds and pulp are represented in Table1.The seeds contain 
110 Afr. J. Food Sci. Technol.

Table 1.Proximate composition of Gardenia sokotensis pulp and seeds

\begin{tabular}{|c|c|c|c|c|c|c|c|}
\hline Paramet & $\begin{array}{c}\text { ter Moisture } \\
(\% \text { WW })\end{array}$ & $\begin{array}{c}\text { Ash } \\
\text { (\%DW) }\end{array}$ & $\begin{array}{c}\text { Crude lipid } \\
(\% \mathrm{DW})\end{array}$ & $\begin{array}{l}\text { Crude protein } \\
\text { (\%DW) }\end{array}$ & $\begin{array}{c}\text { Crude fiber } \\
\text { (\%DW) }\end{array}$ & $\begin{array}{l}\text { Available Carbohydrate } \\
\text { (\%DW) }\end{array}$ & $\begin{array}{r}\text { Energy value } \\
\text { (Kcal per 100g) }\end{array}$ \\
\hline Pulp & $21.7 \pm 0.00$ & $17.88 \pm 0$ & $.41 \quad 53.96 \pm 1.59$ & $6.86 \pm 0.03$ & $13.88 \pm 1.46$ & 7.42 & 1297.28 \\
\hline Seeds & $14.62 \pm 0.01$ & $112.64 \pm 0$ & $47.00 \pm 1.35$ & $13.04 \pm 0.47$ & $17.65 \pm 0.14$ & 9.67 & 1445.87 \\
\hline
\end{tabular}

$\mathrm{WW}=$ wet weight

$\mathrm{DW}=$ dry weight

Table 2. Mineral Composition of pulp and seeds of Gardenia sokotensis fruit ( $\mathrm{mg} / \mathrm{kg}$ dry weight)

\begin{tabular}{|c|c|c|c|c|c|c|c|c|c|c|c|c|c|}
\hline Element & it $\mathrm{Ca}$ & $\mathbf{M g}$ & $\mathrm{Na}$ & $\mathrm{K}$ & $\mathbf{P}$ & $\mathrm{Cu}$ & $\mathrm{Fe}$ & $\mathrm{Zn}$ & Mn & $\mathbf{P b}$ & $\mathrm{Cr}$ & Co & $\mathrm{Ni}$ \\
\hline Pulp & 0.4333 & 0.8266 & 85.830 & 7666.6 & 10.300 & 2.175 & 56.795 & 0.1522 & 0.3101 & 0.0657 & 0.0163 & 0.1195 & $\mathrm{Nd}$ \\
\hline Seeds & 0.6833 & 0.2500 & 106.67 & 75700 & 3.4700 & 1.5298 & 4.2914 & 1.3639 & 0.2615 & 0.0594 & 0.0098 & 0.0447 & $\mathrm{Nd}$ \\
\hline
\end{tabular}

$\mathrm{Nd}=$ not detected

the highest amount of crude protein, crude fiber, carbohydrates and energy value as compared to the pulp. On the other hand, the moisture content, ash content and crude lipid of the pulp are higher than that of the seeds. It is observed in table 1 that the moisture content are higher than those of Balanite aegyptiaca (2.03\% pulp and $11.4 \%$ seeds) as reported by Sadiq et al., (2012) and lower than Star apple (26.55\% pulp and $32.65 \%$ seeds) as reported by Akpabio et al., (2012). The low moisture in the sample offer some storage benefit (Umar and Birnin-Yauri, 2008).

The ash content ranges from $17.88 \%$ to $12.64 \%$ which is higher than that reported for Balanite aegyptiaca, Star apple and Carica papaya morphotypes as reported by Sadiq et al., (2012); Akpabio et al., (2012) and Nwofia et al., (2012) respectively. The high ash content indicates that the fruits may possess high concentration of mineral elements which are expected to speed up metabolic processes, improve growth and development (Hassan et al., 2011). The crude lipid content for pulp and seeds of the fruits are $47.00 \pm 1.35 \%$ and $53.96 \pm$ $1.59 \%$ respectively in comparison to $28.17 \pm 0.04$ and $1.97 \pm 0.00$ in Balanite aegyptiaca fruits is high (Sadiq et al., 2012).

The protein content for pulp and seeds are $6.86 \pm$ $0.03 \%$ and $13.04 \pm 0.47 \%$ which is higher than the seeds but comparable to pulp of Star apple (8.75\% and 6.73\%) as reported by Akpabio et al.,(2012), besides the result of this research is higher than that for Carica papaya morphotypes (Nwofia et al., 2012). The protein is an essential component of diet which supplies adequate amounts of amino acids (Pugalenthi, 2004).

The fibre content for both pulp and seeds of the fruits were found to be $13.88 \pm 1.46 \%$ and $17.65 \pm 0.14 \%$ which is much higher than Annona muricata $8.00 \%$ (Onimawo, 2002). The available carbohydrates content obtained $(7.42 \%$ and $9.67 \%)$ is in accordance with values obtained by karanja et al., (2013) for Pupkin in the case of pulp but higher when compared to that of the seeds.

\section{Mineral analysis}

The results of the mineral composition in the Gardenia sokotensis pulp and seeds are presented in Table 2. The mineral elements determined were $\mathrm{Ca}, \mathrm{Mg}, \mathrm{Na}, \mathrm{K}, \mathrm{P}, \mathrm{Cu}$, $\mathrm{Fe}, \mathrm{Zn}, \mathrm{Mn}, \mathrm{Pb}, \mathrm{Cr}$, Co and $\mathrm{Ni}$. A higher potassium values were observed for both seeds $(7570.0 \mathrm{mg} / \mathrm{kg})$ and pulp $(7666.6 \mathrm{mg} / \mathrm{kg})$ which are much higher than that reported by Akpabio et al., (2012) and for Star apple Jude et al., (2009). Na, P, Fe and Cu content in both pulp (0.1522$85.83 \mathrm{mg} / \mathrm{kg}$ ) and seeds (1.3639-106.67 mg/kg) were relatively moderate. $\mathrm{Ca}, \mathrm{Mg}, \mathrm{Zn}, \mathrm{Mn}, \mathrm{Pb}, \mathrm{Cr}$ and $\mathrm{Co}$ are quite lowfor both pulp (0.0163-0.8266 mg/kg) and seeds $(0.0098-0.6833 \mathrm{mg} / \mathrm{kg})$ while $\mathrm{Ni}$ was not detected.

From the results obtained both the fruit pulp and seeds could contribute in meeting the recommended dietary allowance in term of iron, zinc, copper and chromium. But in term of sodium and potassium the seeds contribute better than the pulp.

\section{Anti-nutritional factors}

The total Oxalate, cyanide, nitrate and phytate of the seeds are higher than that of the pulp as shown in Table 3. However, the tannins content of the pulp is higher than that of the seeds. The results obtained shows that the entire factors are below the recommended toxic level (Birgitta and Gullick, 2000). The anti-nutrient factor interfere metabolic processes so that growth and bio availability of nutrient are negatively influences. These factor stands as indices for judging the nutritional value of any given food substance (Binita and Khetarpual, 1997). 
Table 3. Levels of some anti-nutritive factors in pulp and seeds of Gardenia sokotensis.

\begin{tabular}{llllll}
\hline $\begin{array}{l}\text { Anti-nutritive } \\
\text { factors }\end{array}$ & Hydrocyanide & Nitrate & Phytate & Tannins & Total Oxalate \\
\hline Pulp & 0.12 & 0.04 & 2.03 & 0.38 & 1.10 \\
Seeds & 0.21 & 0.14 & 2.30 & 0.27 & 1.97 \\
\hline
\end{tabular}

Table 4. Phytochemical Screening of Gardenia sokotensis.

\begin{tabular}{llllllll}
\hline Phytochemical & Saponins & Tannins & Steroids & Alkaloid & $\begin{array}{l}\text { Cardiac } \\
\text { glycoside }\end{array}$ & Flavanoids & Anthraquinone \\
\hline Water Extract & ++ & + & ++ & ++ & ++ & + & - \\
Methanol & + & + & ++ & ++ & + & + & - \\
Extract & & & & & & & \\
\hline
\end{tabular}

(+): Trace Amount Present; (++): Abundant Amount Present; (-): No Amount Present

The value obtained for oxalate in seeds and pulp was found to be $1.97 \pm 0.00$ and $1.10 \pm 0.02$ which is lower than $48.75 \pm 5.30$ for Strychno sinnocus Del (Hassan et al., 2014). The oxalate is of concern because of the negative effect on mineral availability. High oxalate diet can increase the risk of renal calcium absorption and has been implicated as source of kidney stones (Chai and Lierbman, 2004). The phytate content of the seeds and pulps was found to be $2.30 \pm 0.01$ and $2.03 \pm 0.00$ which is higher than that reported of Strychno sinnocus pulps (242.9 \pm 8.62 ) by Hassan et al., (2014). The problem with phytate in food is that it can bind some essential mineral nutrient in the digestive tract and result in mineral deficiencies (Bello et al., 2008). The concentration of Hydrocyanic acid content of seeds and pulp are 0.21 \pm 0.00 and $0.12 \pm 0.00$ is higher than $0.08 \pm 0.00$ reported by Hassan et al., (2014) for Strychno sinnocua Del pulp. The results indicates that the fruits of Gardenia sokotensis have hydrocyanic acid content below the toxic level of $35 \mathrm{mg} / 100 \mathrm{~g}$ dry weight and $20 \mathrm{mg} \mathrm{HCN}$ recommended by standard organization of Nigeria (Edijala et al.,1999). This also shows that the level of the acid in the sample is within the acceptable range for human consumption. Only plants with more than $200 \mathrm{mg}$ of hydrocyanic acid equivalent per $100 \mathrm{mg}$ fresh weight are considered dangerous (Betancur-Ancona et al., 2008). The concentration of nitratein the pulp and seeds of the fruit are $0.004 \pm 0.00$ and $0.14 \pm 0.00$ which are low compared to the reported value for Strychnoc innocua Delpulp $0.56 \pm 003$ (Hassan et al., 2014). Higher concentration of nitrate in the food can lead to a disease called methmoglobinaemia which is known to reduce the ability of red blood cells to carry oxygen (Kim-Shapiro et al., 2005). The tannins content of the seeds and pulp of Gardenia sokotensis was found to be $0.27 \pm 0.00$ and $0.38 \pm 0.00$. The results obtained indicates the non toxicity of the pulp and seeds.

\section{Phytochemical screening}

The preliminary phytochemical screening was carried out on the fruit extract and the results obtained indicate the presence of alkaloids, cardiac glycoside, saponins and steroids in appreciable presence while tannins and flavonoid contents were realized just presents. The results of this phytochemicals in the fruit indicated that the plant has some medical properties which can be explained for therapeutic purposes (Mallikharjuna et al., 2007) and (Sofowara, 1993).

\section{CONCLUSION}

From the results of these analyses, it shows that the pulp and seeds of Gardenia sokotensis contribute considerably to the nutrients intake of the people who uses the fruits as a source of their diets. The fruits have higher composition of calorific energy value, lipids and moisture while seeds have higher calorific energy value, lipids and fiber. It also revealed high concentration of sodium, potassium, iron, phosphorus, zinc and copper. Although these fruits parts may not provide all the required micronutrients needed by the body, but seeds would provide moderate concentration of essential nutrients such ascarbohydrate, protein ash and moisture while pulp would provide carbohydrate, protein, fiber and ash among others. The fruits parts also contain most of the essential mineral elements such as calcium, magnesium, chromium, manganese, to meet the recommended daily allowances. Even though no single plant could provide human with adequate level of all nutrient, but when these fruits are used with other food items, it would contribute useful amount of essential nutrient to the diet. Apart from nutritional composition, fruits parts also contain anti-nutrient factors such as phytate, oxalate, nitrate, cyanide and tannins all below 
the recommended toxic level. These factors will not interfere with metabolic process so that growth and bioavailability of nutrients are not negatively influence. The phytochemical analysis carried out on the sample indicated that the fruit contains a number of secondary metabolites that could be a source of traditional medicine. Generally, results and findings from this research agreed favorably with those of other natural plants recommended as food supplement in the literature.

\section{RECOMMENDATION}

From the results, the following recommendations are made

(i) Further studies should be conducted to determined antioxidant activity of the fruit parts.

(ii) A comparative phytochemical analysis should be carried out for riped and unripe fruit to evaluate its medicinal values due to bitter test of the unripe fruits.

(iii)Amino acid analysis should be carried out on the fruit parts.

(iv) Anti-microbial studies should be conducted on the fruits extract.

(v) Structure of the active component should be elucidated.

(vi) Toxicity test should be carried out.

\section{AKNOWLEDGEMENT}

This research was supported by Tertiary Education Trust Fund (TETFUND). We thank our colleagues at Chemistry Department, Shehu Shagari College of Education who provided insight and expertise that greatly assisted the research. We thank the laboratory technician, Malam Ahmad Bodinga, Faculty of Agriculture, Usmanu Danfodiyo University, Sokoto.

\section{REFERENCES}

Adesuyi AO, Awosanya OA, Adaramola FB, Omeonu Al(2012). Nutritional and Phytochemical Screening of" Aloe barbadensis". Curr. Res. J. Biol. Sci. 4(1):4-9.

Ahmed U, Birnin-Yauri UA (2008).Comparative analysis of the nutrient composition of cashew (Anarcadiumoccidentable) apple and nut. Nig. J. Basic Appl. Sci. 16: 87-89

Akpabio UD, Akpakpan AE, Enin GN (2012).Evaluation of proximate compositions and mineral elements in the Star apple peel, pulp and seed. Magnesium(Mg). 6(3.52): 29-49.

AOAC (1990). Official methods of analysis (15 th ed.). Washington D.C USA.Association of Official Analytical Chemists inch. 400- 2200 Wilson Boalevard, Arlinton, Virginia, USA. 2:910-928.

Asaolu MF, Asaolu SS (2002).Proximate and mineral compositions of cooked and uncooked Solanummelongena. Int. J. Food Sci. Nutr. 53(2): 103-107

Bello MO, Falade OS, Adewusi SRA, Olawore NO (2008).Studies on the chemical compositions and anti-nutrients of some lesser known Nigeria fruits. Afr. J. Biotechnol. 7(21): 3972

Betancur-Ancona D, Gallegos-Tintoré S, Delgado-Herrera A Pérez-Flores V, CastellanosRuelas A, Chel-Guerrero L (2008). Some physic-chemical and anti-nutritional properties of raw flours and protein isolates from Mucunapruriens (velvet bean) and
Canavaliaensiformis (jack bean). Int. J. Food Sci. Technol. 43(5): 816-823

Binita R, Khetarpaul N (1997). Probiotic† Fermentation: Effect on Antinutrients and Digestibility of Starch and Protein of Indigenously Developed Food Mixture. Nutr. Health. 11(3):139-147.

Birgitta G, Gullick C (2000).Exploring the Potential of Indigenous Wild Food Plants in Southern Sudan. In Proceeding of a Workshop Held in Lokichoggio, Kenya. Pp.22-25.

Chai W, Liebman M (2004).Assessment of oxalate absorption from almonds and black beans with and without the use of an extrinsic label. J. Urol., 172(3): 953-957.

Edijala JK, Okoh PN, Anigoro R (1999). Chemical assay of cyanide levels of short-time-fermented cassava products in the Abraka area of Delta State, Nigeria. Food chem. 64(1): 107-110.

Hassan LG, Abdulmumin U, Umar KJ, Ikeh OP, Aliero AA (2014). Nutritional and anti-nutritional composition of Strychnosinnocua Del.(Monkey Orange) fruit pulp grown in Zuru, Nigeria. Niger. J. Basic Appl. Sci. 22(1-2): 33-37.

Hassan LG, Umar KJ, Dangoggo SM, Maigandi AS (2011). Anti-nutrient composition and bioavailability prediction as exemplified by calcium, iron and zinc in Melociacorchorifolia leaves. Pakistan J. Nutr. 10(1): 23-28.

Hockett ME, Hopkins FM, Lewis MJ, Saxton AM, Dowlen HH, Oliver SP, Schrick FN (2000). Endocrine profiles of dairy cows following experimentally induced clinical mastitis during early lactation. Animal Reproduct. Sci. 58(3): 241-251.

James OS (1995).Anlytical Chemistry by of Food Chapman and Hill. London. Pp.64-65.

Jude Cl, Catherine $\mathrm{Cl}$, Ngozi Ml (2009).Chemical profile of Tridaxprocumbens Linn. Pakistan J. Nutr. 8(5): 548-550.

Karanja JK, Mugendi JB, Fathiya MK, Muchugi AN (2013). Comparative study on the nutritional value of the pumpkin, cucurbita maxima varieties from different regions in kenya. In Scientific Conference Proceedings.

Kim-Shapiro DB, Gladwin MT, Patel RP, Hogg N (2005). The reaction between nitrite and hemoglobin: the role of nitrite in hemoglobinmediated hypoxic vasodilation. J. Inorg. Biochem. 99(1): 237-246.

Krishna G, RanjhanSK(1980). Laboratory manuel for nutrition Research, Vikas Publishing House PVT Ltd. Ghaziabad,Up (India).

Mallikharjuna PB, Rajanna LN, Seetharam YN, Sharanabasappa GK (2007). Phytochemical studies of Strychnospotatorum Lf-A medicinal plant. J. Chem. 4(4): 510-518.

Nwofia GE, Ojimelukwe P, Eji C (2012). Chemical composition of leaves, fruit pulp and seeds in some Carica papaya (L)morphotypes. Int. J. Med. Aromatic Plants. 2(1): 200-206.

Ola FC, Obah G (2000). Food value of two Nigerian Edible Mushroom. J. Technosci. 4: 1-3.

OmoruyiFO, Dilworth L, Asemota HN (2007). Anti-nutritional factors, zinc, iron and calcium in some Caribbean tuber crops and the effect of boiling or roasting. Nutr. Food Sci. 37(1): 8-15.

Onimawo IA (2002). Proximate composition and selected physicochemical properties of the seed, pulp and oil of sour (Annonamuricata). Plant foods for human Nutrition. 57:165-171.

Ozaki A, Kitano M, Furusawa N, Yamaguchi H, Kuroda K, Endo G (2002). Genotoxicity of gardenia yellow and its components. Food Chem. Toxicol. 40(11): 1603-1610.

Pugalenthi M, Vadivel V, Gurumoorthi $P$, Janardhanan K (2004).Comparative nutritional evaluation of little known legumes, Tamarindusindica, Erythrinaindica and Sesbaniabispinosa. Tropical and Subtropical Agroecosystems. 4(3): 107-123.

Sadiq TS, Dangoggo SM, Hassan L.G, Manga SB, Thamson I, Itodo AU (2012). Nutritional Composition of Aduwa Fruits (Balanitesaegyptiaca) from Semi arid region, North-Western Nigeria. Int. J. Food Nutri. Sci. 2: 7-9

Sofowora AO (1993). Traditional Medicine and medicinal plants in Africa.University of Ife preee 2nd (Edn), pp.320.

Umar A,Birnin-Yauri UA (2008). Proximate Analysis of Cashew Nut Oil, its Industrial Potentials. Kontagora J. Sci. Technol. 5 (1): 37 - 41. 